Research Article

\title{
Discotic Liquid Crystals Based on Cu(I) Complexes with Benzoylthiourea Derivatives Containing a Perfluoroalkyl Chain
}

\author{
Monica Iliş and Viorel Cîrcu $(D$ \\ Department of Inorganic Chemistry, University of Bucharest, 23 Dumbrava Rosie St., Sector 2, Bucharest 020464, Romania \\ Correspondence should be addressed to Viorel Cîrcu; viorel.circu@chimie.unibuc.ro
}

Received 11 May 2018; Accepted 19 June 2018; Published 8 July 2018

Academic Editor: Pedro M. Mancini

Copyright (C) 2018 Monica Iliş and Viorel Cîrcu. This is an open access article distributed under the Creative Commons Attribution License, which permits unrestricted use, distribution, and reproduction in any medium, provided the original work is properly cited.

\begin{abstract}
Mesomorphic three-coordinate copper(I) complexes $\left(\left[\mathrm{Cu}(\mathrm{BTU})_{2} \mathrm{X}\right]\right.$, where $\mathrm{X}=\mathrm{Cl}$ or $\left.\mathrm{Br}\right)$ based on a new $N$-benzoylthiourea (BTU) ligand with two decyloxy and one perfluorooctyl groups at its periphery were designed and prepared. The BTU ligand coordinates via the $\mathrm{S}$ atom in a neutral monodentate fashion as confirmed by IR and NMR spectroscopy data. The liquid crystalline behavior of these copper(I) complexes was investigated by a combination of polarized optical microscopy (POM), differential scanning calorimetry (DSC), and X-ray diffraction analysis (XRD), while their thermal stability was studied by thermogravimetric analysis (TGA). These new copper(I) complexes have mesomorphic properties and exhibit a hexagonal columnar mesophase over a large temperature range, more than $100^{\circ} \mathrm{C}$.
\end{abstract}

\section{Introduction}

Liquid crystalline compounds (LC) based on metal complexes (metallomesogens) represent a special class of liquid crystals with interesting properties related to metal ions employed, such as luminescence, magnetism, redox properties, and so on $[1,2]$. The unique properties of thermotropic liquid crystals, in particular their electrooptical properties [3-7], have led to various applications (LCD, molecular sensors and detectors, optical switches, spatial light modulator, etc.) [8-10]. Metallomesogens based on copper(I) complexes are quite rare, even if the copper(I) can form complexes with low coordination number suitable for the stabilization of LC phases. The copper(I) complexes with liquid crystalline properties reported so far are restricted to few classes of ligands related to alkylthiolates [11], isocyanides [12-16], phenantroline [17], azamacrocycles [18], or Schiff bases derived from 2-iminopyridines $[19,20]$, giving rise to either mono- or binuclear two- or tetracoordinate complexes. Ionic columnar metallomesogens formed by three-coordinate copper(I) complexes with bis(1pyrazolyl)ethyl ether ligands were reported by Lin and Lai [21]. In this study, we report a new class of copper(I) metallomesogens based on neutral copper(I) three-coordinate complexes with benzoylthiourea (BTU) ligands. These benzoylthiourea derivatives (BTU) proved to have excellent properties to bind to various metal ions due to the very strong donor groups (carbonyl and thioamide) that yield various transition metal complexes. The BTU ligands can give neutral homoleptic or heteroleptic complexes either with $S$ - and $O$ coordination, when the ligand is coordinated in monoanionic bidentate form by deprotonation or with only $S$-coordination if the ligand is bound in neutral form to the metal center [22-32]. The reaction between copper(II) salts and, more generally, the versatile acylthiourea compounds leads to a variety of copper(I) complexes, including tetra- and threecoordinate mononuclear complexes, halide-bridged dinuclear complexes, or cluster-type polynuclear complexes, depending on the halide type and reaction conditions [33-39]. The complexity of the redox reaction between the copper(II) salts and thiourea compounds results from the combination between the versatility of the acylthiourea ligands and the coordination flexibility of the copper(I) ion. The threecoordinate copper(I) complexes, which possess two molecules of the BTU ligand linked via the sulfur atom and one halide ion, have approximately an overall planar shape 
[37-39]. The molecular shape arguments indicate that such complexes could be potential candidates for new liquid crystalline materials after careful functionalization of BTU derivatives with suitable mesogenic groups. The BTU compounds having terminal alkoxy groups at the both ends of the molecule show interesting mesogenic behavior, displaying nematic, smectic $\mathrm{A}$, and smectic $\mathrm{C}$ phases, depending on the position and length of the alkyl chains [40]. On the contrary, partially fluorinated BTU compounds show comparable mesogenic properties, with an increased stability of lamellar phases and higher transition temperatures [41]. It is well known that the alkyl chains substitution with semi- or perfluoroalkylated chains leads to a serious increasing of both the transition temperatures and mesophases thermal ranges $[42,43]$. Moreover, the stability of layered phases for such compounds with perfluoroalkyl groups is significantly increased due to the incompatibility between the aliphatic and perfluoroalkylated chains as well as the rigidity of the latter [44-50].

This paper reports the preparation and mesogenic behavior of a new class of copper(I) metallomesogens based on copper(I) halide complexes (chloride or bromide) with a novel benzoylthiourea ligand that have at one side two decyloxy chains and, at the other side, a perfluorooctyl group. The liquid crystalline properties of the new three-coordinate copper(I) complexes were studied by a combination of differential scanning calorimetry (DSC) and polarizing optical microscopy (POM). Moreover, these new complexes have mesomorphic properties and exhibit a columnar mesophase over a large temperature range, more than $100^{\circ} \mathrm{C}$, as shown by DSC.

\section{Experimental}

2.1. Characterization Methods. All the chemicals were used as supplied. $\mathrm{C}, \mathrm{H}$, and $\mathrm{N}$ analyses were carried out with an EuroEA 3300 instrument. IR spectra were recorded on a Bruker spectrophotometer using $\mathrm{KBr}$ discs. ${ }^{1} \mathrm{H}$ and ${ }^{13} \mathrm{C}$ NMR spectra were recorded on a Bruker spectrometer operating at $500 \mathrm{MHz}$, using $\mathrm{CDCl}_{3}$ as solvent. ${ }^{1} \mathrm{H}$ chemical shifts were referenced to the solvent peak position, $\delta$ $7.26 \mathrm{ppm}$. The phase assignments for the BTU ligand and its copper(I) complexes were evaluated by polarizing optical light microscopy (POM), placed on untreated glass slides, using a Nikon 50iPol microscope equipped with a Linkam THMS600 hot stage and TMS94 control processor. Temperatures and enthalpies of transitions were recorded by using the differential scanning calorimetry (DSC) technique employing a Diamond DSC PerkinElmer instrument. The BTU ligand and its copper(I) complexes were studied at $10 \%$ min of scanning rate after being encapsulated in aluminium pans. Three heating/cooling cycles were performed on each sample. Thermogravimetric analysis for all samples was performed on a TA Q50 TGA instrument using alumina crucibles and nitrogen as purging gas. The heating rate employed was $10^{\circ} \mathrm{C} \cdot \mathrm{min}^{-1}$ from room temperature to $550^{\circ} \mathrm{C}$. The powder XRD measurements were made on a D8 Advance diffractometer (Bruker AXS $\mathrm{GmbH}$, Germany), in parallel beam setting, with monochromatized $\mathrm{Cu}-\mathrm{K} \alpha 1$ radiation $(\lambda=1.5406 \AA)$, scintillation detector, and horizontal sample stage. The measurements were performed in symmetric $(\theta-\theta)$ geometry in the $2 \theta$ range from $1.5^{\circ}$ to $30^{\circ}$ in steps of $0.02^{\circ}$, with measuring times per step in the $5-40 \mathrm{~s}$ range. The temperature control of the samples during measurements was achieved by adapting a home-made heating stage to the sample stage of the diffractometer.

\subsection{Preparation of N-(4-Perfluorooctylphenylcarbamothioyl)-} 3,4-didecyloxybenzamide (1). The synthesis of the BTU ligand 1 followed the procedure described elsewhere [40, 41]. In the first step, the acid chlorides were prepared by reacting the 3,4-didecyloxybenzoic acid $(5 \mathrm{mmol})$ with an excess of thionyl chloride $(20 \mathrm{mmol})$ in freshly distilled dichloromethane $(25 \mathrm{ml})$ for 3 hours and heating under reflux. Then, the excess of thionyl chloride and the solvent were removed under reduced pressure. The resulting acid chloride was taken to the next step without further purification. The acid chloride was dissolved in dry acetone $(20 \mathrm{ml})$, and a solution of $\mathrm{NH}_{4} \mathrm{SCN}(5 \mathrm{mmol})$ in acetone $(15 \mathrm{~mL})$ was added dropwise for a period of $15 \mathrm{~min}$ under nitrogen. The mixture was heated under reflux for a period of $30 \mathrm{~min}$. During the addition of the ammonium thiocyanate solution, the formation of a cloudy white precipitate was observed. The mixture was cooled down to room temperature, and a solution of $p$-perfluorooctylaniline $(4.6 \mathrm{mmol})$ in acetone $(10 \mathrm{~mL})$ was added dropwise for a period of $30 \mathrm{~min}$. The mixture was further stirred for 2 hours at room temperature, and then it was poured in $100 \mathrm{ml}$ of deionized water. The resulting precipitate was filtered off and washed several times with water and ethanol followed by two times of recrystallization from a mixture of dichloromethane/ethanol to yield a white solid.

2.2.1. Compound 1. White crystalline solid. Yield: $77 \%$. Anal. Calcd. For $\mathrm{C}_{42} \mathrm{H}_{51} \mathrm{~F}_{17} \mathrm{~N}_{2} \mathrm{O}_{3} \mathrm{~S}$ (\%): C, 51.11; H, 5.21; and $\mathrm{N}, 2.84$; Found: C, 51.59; H, 5.35; and N, 2.65. ${ }^{1} \mathrm{H}$ NMR $\left(500 \mathrm{MHz}, \mathrm{CDCl}_{3}\right) \delta 12.99(\mathrm{~s}, 1 \mathrm{H}), 9.05(\mathrm{~s}, 1 \mathrm{H}), 7.98(\mathrm{~d}$, $J=8.6 \mathrm{~Hz}, 2 \mathrm{H}), 7.74(\mathrm{~d}, J=8.6 \mathrm{~Hz}, 2 \mathrm{H}), 7.60-7.30(\mathrm{~m}, 2 \mathrm{H})$, $6.93(\mathrm{~d}, J=8.2 \mathrm{~Hz}, 1 \mathrm{H}), 4.24-3.71(\mathrm{~m}, 4 \mathrm{H}), 1.93-1.80(\mathrm{~m}$, $4 \mathrm{H})$, and $1.55-1.20(\mathrm{~m}, 28 \mathrm{H}), 0.88(\mathrm{~m}, 6 \mathrm{H}) .{ }^{13} \mathrm{C} \mathrm{NMR}$ $\left(126 \mathrm{MHz}, \mathrm{CDCl}_{3}, \mathrm{ppm}\right) \delta: 178.5,166.4,154.2,149.6,141.1$, $127.7,127.6,126.5,123.3,123.0,121.1,119.6,112.4,112.1$, 69.6, 69.3, 31.8, 29.6, 29.4, 29.3, 29.1, 29.0, 26.1, 25.9, 22.7, and 14.1. IR $\left(\mathrm{KBr}, \mathrm{cm}^{-1}\right): 3266\left(\nu_{\mathrm{NH}}\right), 2924,2853\left(\nu_{\mathrm{CH}_{2}}\right), 1665$ $\left(\nu_{\mathrm{C}=\mathrm{O}}\right), 1503\left(\nu_{\mathrm{C}-\mathrm{N}}\right), 1350\left(\nu_{\mathrm{C}=\mathrm{S}}\right)$, and $1144\left(\nu_{\mathrm{C}-\mathrm{N}}\right)$.

2.3. Preparation of Copper(I) Complexes ( $2 \boldsymbol{a}$ and $\mathbf{2 b}$ ). The synthesis of copper(I) complexes with benzoylthiourea ligand $\mathbf{1}$ is similar to the preparation of such copper(I) complexes described elsewhere [36, 38, 39]. A solution of the corresponding halide copper(II) salt $\left(\mathrm{CuX}_{2}\right.$, where $\mathrm{X}=\mathrm{Cl}$ or $\mathrm{Br} ; 0.5 \mathrm{mmol})$ dissolved in ethanol $(5 \mathrm{ml})$ was added dropwise over a period of $5 \mathrm{~min}$ to a hot solution of the ligand $(1 \mathrm{mmol})$ in ethanol $(10 \mathrm{ml})$. A bright-yellow precipitate was formed during the addition of the solution of copper(II) salt. The mixture was further stirred and heated 
under reflux for 2 hours. After this period of time, the hot mixture was filtered and the resulting precipitate was washed several times with ethanol and dried in vacuum to yield a yellow solid. The yields were calculated based on copper salts. The ${ }^{1} \mathrm{H}$ NMR spectroscopy and the elemental analysis confirmed the formation and purity of these copper(I) complexes.

2.3.1. Compound $2 \boldsymbol{a}$. Yellow solid. Yield: $74 \%$. Anal. Calcd. For $\mathrm{C}_{84} \mathrm{H}_{102} \mathrm{ClCuF}_{34} \mathrm{~N}_{4} \mathrm{O}_{6} \mathrm{~S}_{2}(\%)$ : C, 48.67; $\mathrm{H}, 4.96$; and $\mathrm{N}$, 2.70; Found: C, 49.23; H, 4.84; and N, 2.74. ${ }^{1} \mathrm{H}$ NMR $\left(500 \mathrm{MHz}, \mathrm{CDCl}_{3}, \mathrm{ppm}\right) \delta 13.35(\mathrm{~s}, 2 \mathrm{H}), 11.06(\mathrm{~s}, 2 \mathrm{H})$, 8.16-7.92 (m, 2H), 7.70-7.62 (m, 10H), $6.89(\mathrm{~d}, J=8.6 \mathrm{~Hz}$, $2 \mathrm{H}), 4.09(\mathrm{t}, J=6.5 \mathrm{~Hz}, 4 \mathrm{H}), 4.03(\mathrm{t}, J=6.5 \mathrm{~Hz}, 4 \mathrm{H}), 2.05-1.69$ $(\mathrm{m}, 8 \mathrm{H}), 1.51-1.20(\mathrm{~m}, 56 \mathrm{H})$, and $0.88(\mathrm{~m}, 12 \mathrm{H})$.

${ }^{13} \mathrm{C}$ NMR $\left(126 \mathrm{MHz}, \mathrm{CDCl}_{3}\right) \delta 179.1,169.0,154.6,148.9$, $139.9,127.8,125.4,123.9,122.2,113.4,111.7,69.5,69.1,31.9$, $30.9,29.6,29.5,29.3,29.2,29.1,26.0,22.7,22.3$, and 14.1 .

IR $\left(\mathrm{KBr}, \mathrm{cm}^{-1}\right): 3274\left(\nu_{\mathrm{NH}}\right), 2927,2856\left(v_{\mathrm{CH}_{2}}\right), 1664$ $\left(v_{\mathrm{C}=\mathrm{O}}\right), 1512\left(v_{\mathrm{C}-\mathrm{N}}\right)$, and $1152\left(v_{\mathrm{C}-\mathrm{N}}\right)$.

2.3.2. Compound $2 \boldsymbol{b}$. Yellow solid. Yield: $78 \%$. Anal. Calcd. For $\mathrm{C}_{84} \mathrm{H}_{102} \mathrm{BrCuF}_{34} \mathrm{~N}_{4} \mathrm{O}_{6} \mathrm{~S}_{2}(\%)$ : $\mathrm{C}, 47.65 ; \mathrm{H}, 4.86$; and $\mathrm{N}$, 2.65; Found: $\mathrm{C}, 48.51 ; \mathrm{H}, 4.64$; and $\mathrm{N}, 2.66 .{ }^{1} \mathrm{H}$ NMR $\left(500 \mathrm{MHz}, \mathrm{CDCl}_{3}, \mathrm{ppm}\right) \delta 13.27(\mathrm{~s}, 2 \mathrm{H}), 10.66(\mathrm{~s}, 2 \mathrm{H}), 7.98$ $(\mathrm{d}, 7.8 \mathrm{~Hz}, 2 \mathrm{H}), 7.68(\mathrm{~m}, 4 \mathrm{H}), 7.59(\mathrm{~m}, 6 \mathrm{H}), 6.88(\mathrm{~d}$, $J=8.6 \mathrm{~Hz}, 2 \mathrm{H}), 4.09(\mathrm{t}, J=6.5 \mathrm{~Hz}, 4 \mathrm{H}), 4.01(\mathrm{t}, J=6.5 \mathrm{~Hz}$, $4 \mathrm{H}), 1.97-1.65(\mathrm{~m}, 8 \mathrm{H}), 1.50-1.11(\mathrm{~m}, 56 \mathrm{H})$, and $0.88(\mathrm{~m}$, $12 \mathrm{H})$.

${ }^{13} \mathrm{C}$ NMR $\left(126 \mathrm{MHz}, \mathrm{CDCl}_{3}\right) \delta 178.4,168.6,154.7,149.0$, $139.9,127.8,125.1,123.8,122.1,113.3,111.7,69.6,69.1,31.9$, $29.6,29.5,29.4,29.3,29.2,29.0,26.0,22.7$, and 14.1.

IR $\left(\mathrm{KBr}, \mathrm{cm}^{-1}\right): 3275\left(\nu_{\mathrm{NH}}\right), 2927,2856\left(\nu_{\mathrm{CH}_{2}}\right), 1665$ $\left(v_{\mathrm{C}=\mathrm{O}}\right), 1510\left(\nu_{\mathrm{C}-\mathrm{N}}\right)$, and $1152\left(\nu_{\mathrm{C}-\mathrm{N}}\right)$.

\section{Results and Discussions}

3.1. Synthesis. The novel BTU ligand having two terminal decyloxy chains on the benzoyl unit and a perfluorooctyl group on the aniline fragment was prepared through the reaction of 3,4-didecyloxybenzoyl isothiocyanate with 4perfluorooctylaniline in high yield $(77 \%)$ (Scheme 1) $[40,41,51]$. The copper(I) complexes were obtained by reaction of the BTU ligand with copper(II) halide salts in hot ethanol in a 2:1 molar ratio to give yellow solids. The reaction can be also performed by employing copper(I) salts giving identical products. The new BTU derivative and the copper(I) complexes were fully characterized by ${ }^{1} \mathrm{H}$ NMR and ${ }^{13} \mathrm{C}$ NMR and IR spectroscopies as well as by elemental analyses. The ${ }^{1} \mathrm{H}$ NMR spectrum of BTU ligand $\mathbf{1}$ contains two singlets, one at $9.05 \mathrm{ppm}$ and a second one at $12.99 \mathrm{ppm}$, which can be assigned to the two NH groups. The first singlet can be assigned to the $\mathrm{NH}$ proton located between the carbonyl and thiocarbonyl groups, while the second singlet was assigned to the $\mathrm{NH}$ proton between the thiocarbonyl group and the benzene ring. On the contrary, the chemical shift values for the carbonyl and thiocarbonyl carbons were found at about $166.5 \mathrm{ppm}$ and around $178.5 \mathrm{ppm}$, respectively, as reported for some other fluorinated BTU compounds $[52,53]$.

The ${ }^{1} \mathrm{H}$ NMR spectra of copper(I) complexes recorded in $\mathrm{CDCl}_{3}$ solvent show the expected signals assigned to ligand with several significant shifts resulted from its coordination to the copper(I) center (Figure 1). The most significant changes were seen for the two NH singlets. Both signals were downfield shifted with a more pronounced shift for the signal assigned to the $\mathrm{NH}$ group located between the carbonyl and thiocarbonyl groups of the BTU ligand.

While the first singlet at $12.99 \mathrm{ppm}$ in the ${ }^{1} \mathrm{H}$ NMR spectrum of uncoordinated ligand downfield shifts to $13.35 \mathrm{ppm}$ for $\mathbf{2 a}$ and to $13.27 \mathrm{ppm}$ for $\mathbf{2} \mathbf{b}$, the second $\mathrm{NH}$ signal at $8.99 \mathrm{ppm}$ for $\mathbf{1}$ is downfield shifted to $11.06 \mathrm{ppm}$ for $2 \mathbf{a}$ and to $10.66 \mathrm{ppm}$ for $\mathbf{2 b}$ as a consequence of the intramolecular hydrogen bonding between the halide ion and the second NH group. These chemical shift changes are attributed to the copper(I) complexes formation, and similar results were found for related three-coordinate copper(I) complexes [33-35]. Intramolecular hydrogen-bonding between the coordinated halide ions and $\mathrm{NH}$ group was evidenced by X-ray structural analysis for several related complexes [37-39].

Several regions of the FTIR spectra, recorded in $\mathrm{KBr}$ discs, are of interest for supporting the coordination via the sulfur atom: $3200-3400 \mathrm{~cm}^{-1}$ for $\nu_{\mathrm{N}-\mathrm{H}}$ frequencies, $1500-1700 \mathrm{~cm}^{-1}$ for strong $\nu_{\mathrm{C}=\mathrm{O}}$ and $\nu_{\mathrm{C}-\mathrm{N}}$ frequencies, and finally, $1100-1250 \mathrm{~cm}^{-1}$ where strong absorption bands assigned to a combination of $\nu_{\mathrm{C}-\mathrm{N}}$ and $\nu_{\text {phenyl }}$ stretching frequencies can be found [54-58]. For example, the intensity and the position of the carbonyl stretching $\nu_{\mathrm{C}=\mathrm{O}}$ at $\sim 1665 \mathrm{~cm}^{-1}$ are essentially the same in the IR spectra of $2 \mathrm{a}$ and $\mathbf{2 b}$ as in the free ligand $\mathbf{1}$. The medium intense band at $1350 \mathrm{~cm}^{-1}$ in the IR of ligand $\mathbf{1}$, assigned to $\nu_{\mathrm{C}=\mathrm{S}}$, is absent in the IR spectra of copper(I) complexes [34]. Additionally, the very strong band at $1144 \mathrm{~cm}^{-1}$ for $\mathbf{1}$, corresponding to $v_{\mathrm{C}-\mathrm{N}}$ of the thioamide group, shifts to higher wavenumber at $1152 \mathrm{~cm}^{-1}$ for $\mathbf{2 a}$ and $\mathbf{2 b}$.

3.2. Liquid Crystalline Properties. The new copper(I) complexes and the benzoylthiourea ligand were investigated for their liquid crystalline properties by a combination of hotstage polarizing optical microscopy (POM) and differential scanning calorimetry (DSC). The thermal parameters for all compounds are presented in Table 1.

The heating run of the DSC curve recorded for ligand $\mathbf{1}$ shows only one transition assigned to a crystal-to-isotropic state transition (Table 1). On cooling from the isotropic state down to $0^{\circ} \mathrm{C}$, three transitions were observed, an isotropic to a crystalline phase $\left(\mathrm{Cr}_{1}\right)$ transition followed by other two transitions between crystalline states $\left(\mathrm{Cr}_{2}\right.$ and $\left.\mathrm{Cr}_{3}\right)$. No LC phase was evidenced for the BTU ligand. On the contrary, it was found that both copper(I) complexes show mesogenic properties.

Two transitions were detected in the DSC traces both during the heating and cooling runs for the two copper(I) complexes: a first transition from the isotropic state to a columnar phase followed by a second transition assigned to a glass transition around $50^{\circ} \mathrm{C}$ (Figures 2 and 3). All these 

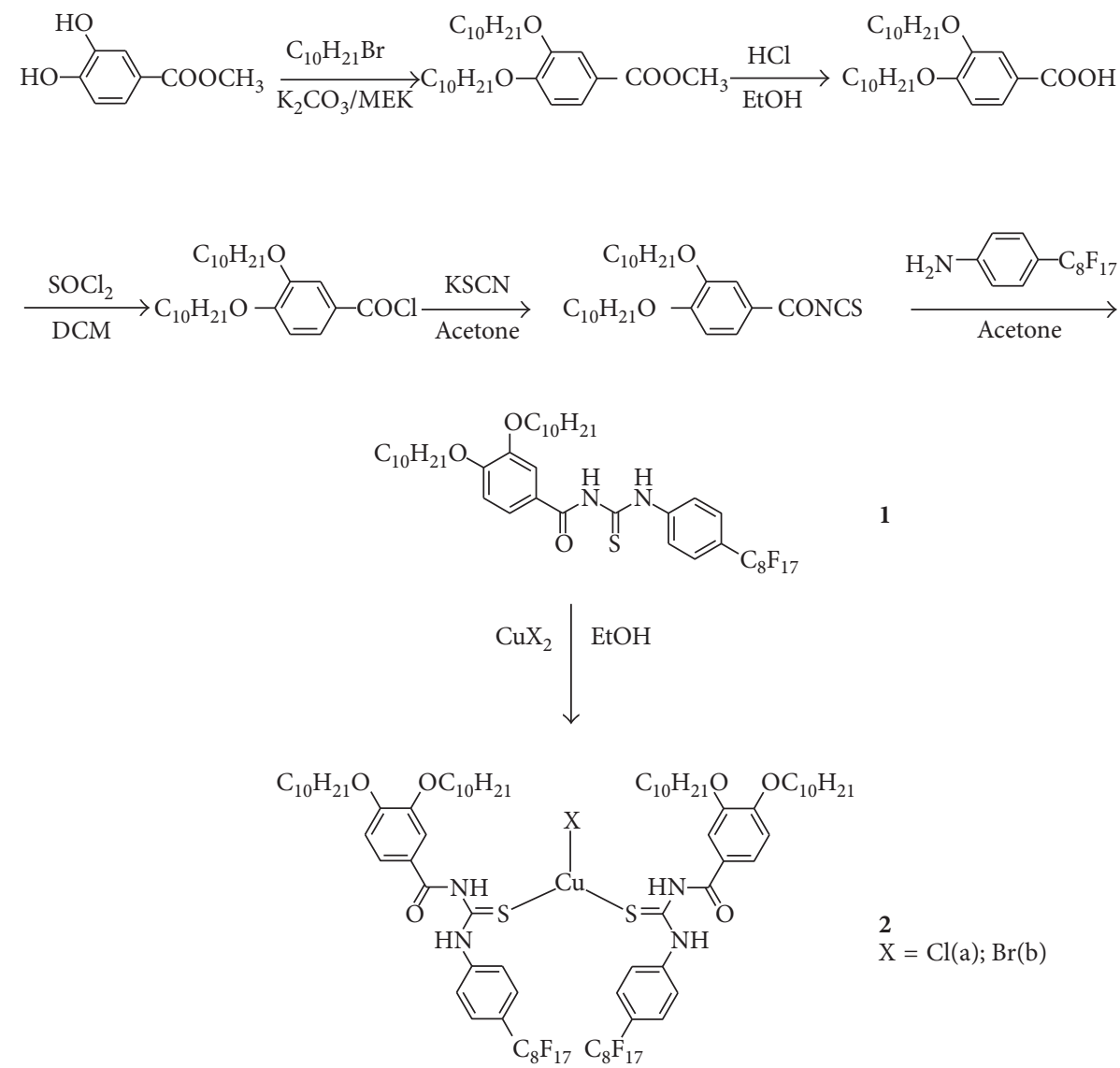

$\mathrm{X}=\mathrm{Cl}(\mathrm{a}) ; \mathrm{Br}(\mathrm{b})$

Scheme 1: Synthesis of $N$-benzoyl- $N^{\prime}$-arylthiourea perfluoroalkyl terminated BTU and of copper(I) complexes.
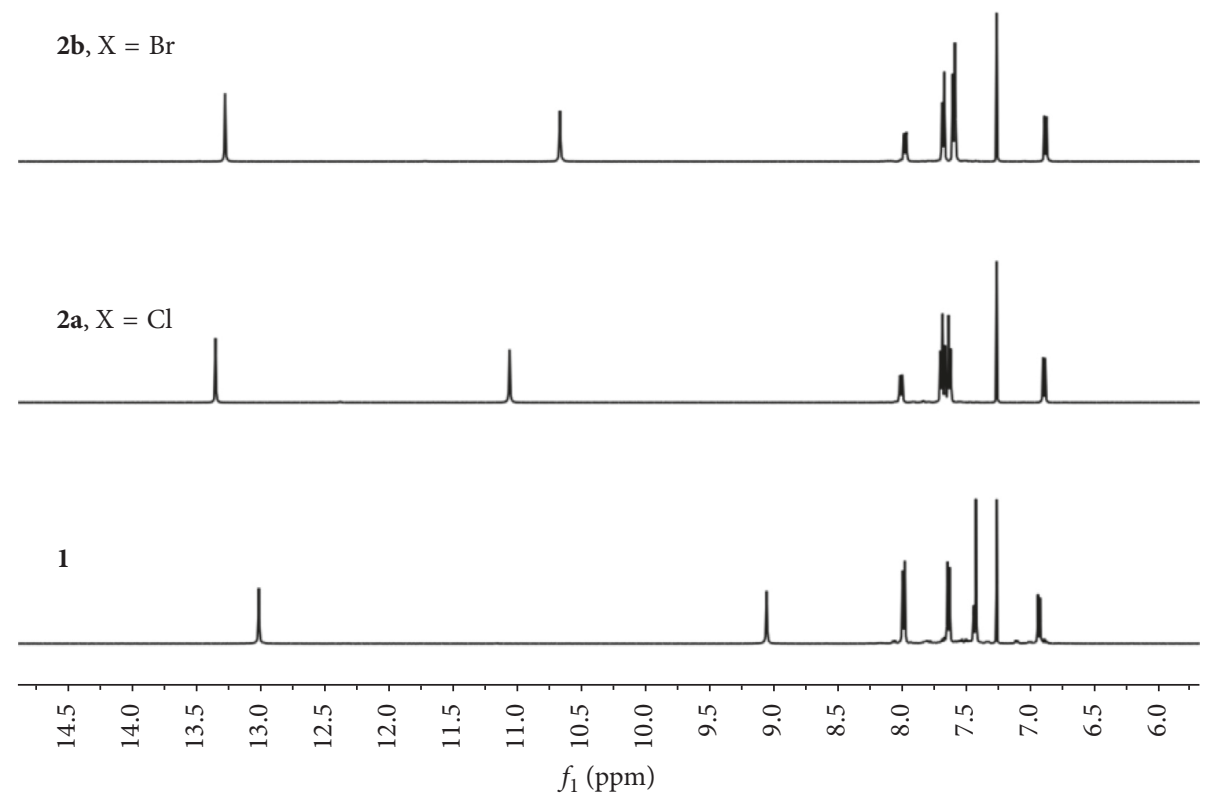

Figure 1: The low field region of the ${ }^{1} \mathrm{H}$ NMR spectra of the benzoylthiourea derivative $\mathbf{1}$ and its copper(I) complexes $\mathbf{2 a}$ and $\mathbf{2} \mathbf{b}$.

transitions were detected by POM as well, and an example of textural changes for compound $\mathbf{2} \mathbf{a}$ is presented in Figure 4. These results are consistent with the POM studies, where typical optical textures of a hexagonal columnar $\left(\mathrm{Col}_{\mathrm{h}}\right)$ phase were observed for both copper(I) complexes (Figures 4 and 5). The clearing temperatures of the two copper(I) complexes (Table 1, measured during the first heating run) depend significantly on the size of the halide ion. 
TABle 1: Transition temperatures $\left(\mathrm{in}{ }^{\circ} \mathrm{C}\right.$ ) and enthalpies $\left(\mathrm{kJ} \cdot \mathrm{mol}^{-1}\right)$ for ligand $\mathbf{1}$ and its copper(I) complexes.

\begin{tabular}{|c|c|}
\hline Compound & Transitions, $\mathrm{T} /{ }^{\circ} \mathrm{C}\left(\Delta \mathrm{H} / \mathrm{kJ} \cdot \mathrm{mol}^{-1}\right)^{\mathrm{a}}$ \\
\hline 1 & $\begin{array}{c}\text { Cr } 110 \text { (58.7) Iso } 99(-35.0) \mathrm{Cr}_{1} 87 \\
\text { (-7.1) } \mathrm{Cr}_{2} 17(-7.7) \mathrm{Cr}_{3}\end{array}$ \\
\hline $2 \mathbf{a}$ & g $50^{\mathrm{b}} \mathrm{Col}_{\mathrm{h}} 162(13.7)$ Iso $162(-13.0) \mathrm{Col}_{\mathrm{h}} 50^{\mathrm{b}} \mathrm{g}$ \\
\hline $2 b$ & g $52 \mathrm{Col}_{\mathrm{h}} 173(18.2)$ Iso $170(-16.3) \mathrm{Col}_{\mathrm{h}} 47 \mathrm{~g}$ \\
\hline
\end{tabular}

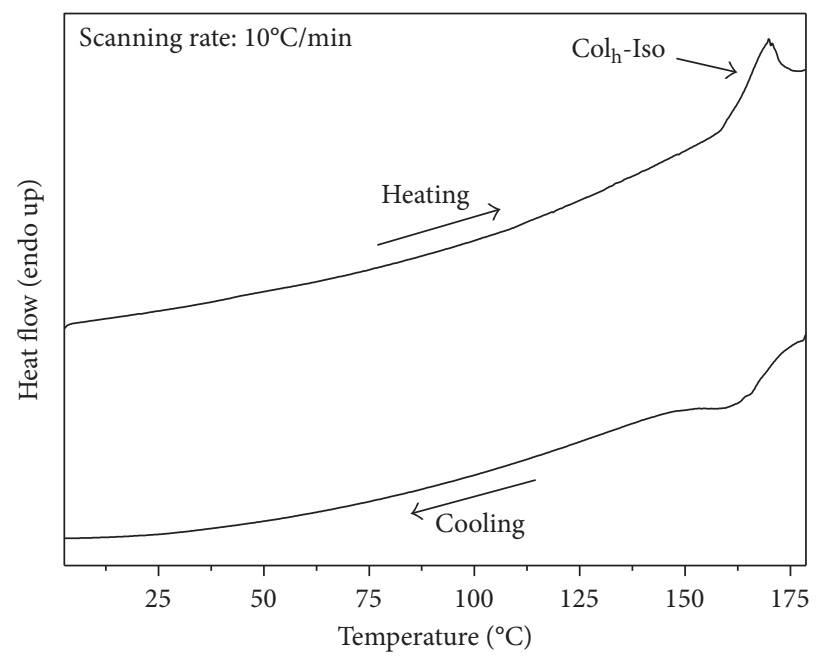

(a)

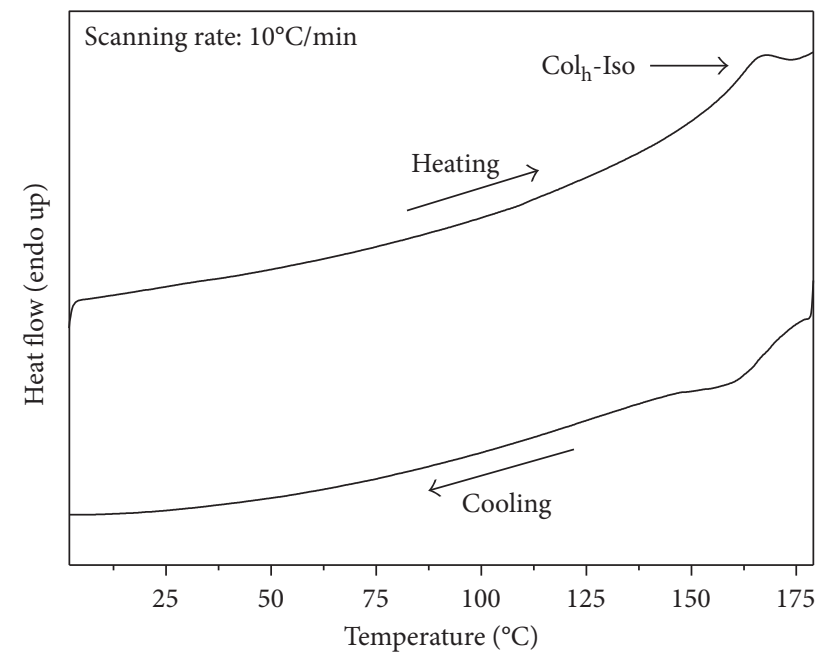

(b)

FIGURE 2: DSC traces for 2a: first (a) and second heating-cooling cycles (b).

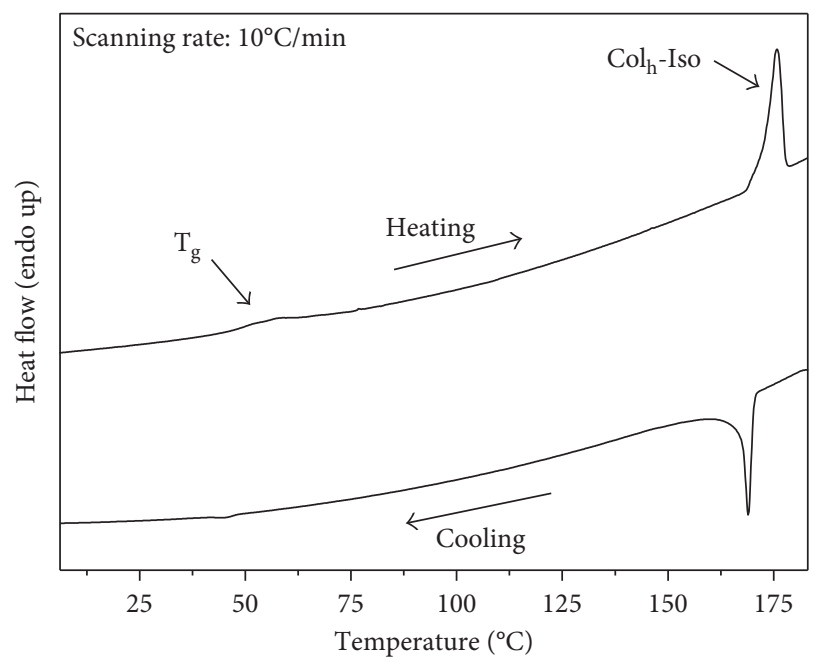

(a)

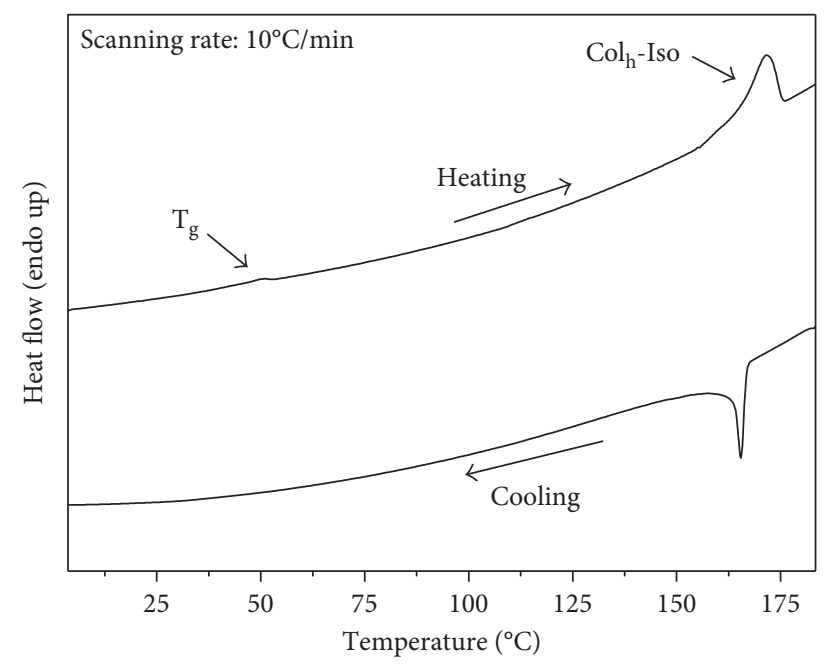

(b)

FIGURE 3: DSC traces for $\mathbf{2 b}$ : first (a) and second heating-cooling cycles (b).

The lowest clearing temperature was recorded for chlorocomplex $2 \mathrm{a}\left(162^{\circ} \mathrm{C}\right)$, while a higher clearing temperature was measured for the bromocomplex $2 \mathbf{b}\left(173^{\circ} \mathrm{C}\right)$. Interestingly, these two copper(I) compounds are stable in the glassy state at room temperature as no crystalline phases were seen during the first and subsequent heating-cooling cycles.
The mesophase assignment for the two $\mathrm{Cu}(\mathrm{I})$ complexes was confirmed further by powder X-ray diffraction (XRD) measurements (Table 2). The samples were heated up to $125^{\circ} \mathrm{C}$ in the mesomorphic domain, and typical patterns that are characteristic of a hexagonal packing were obtained in each case. 


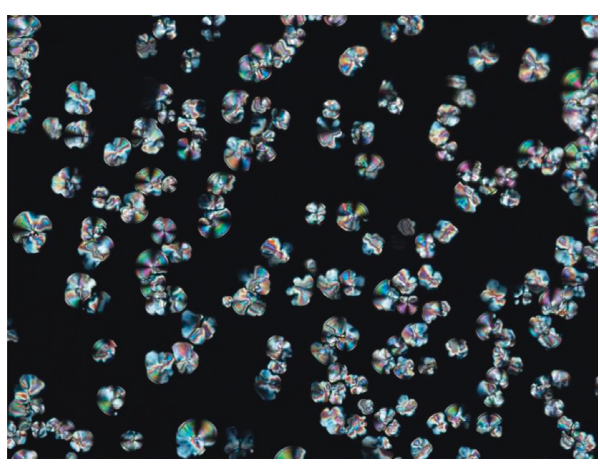

(a)

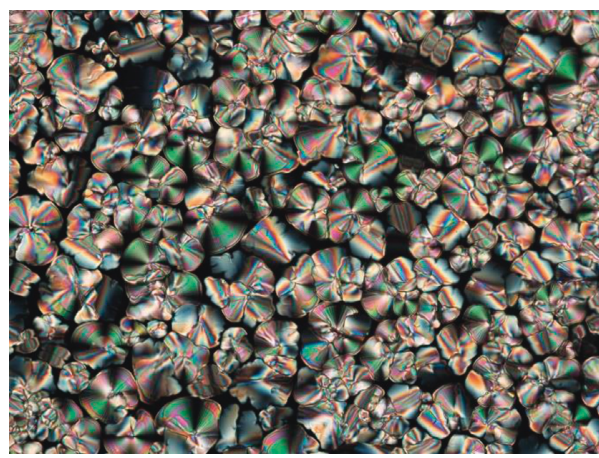

(c)

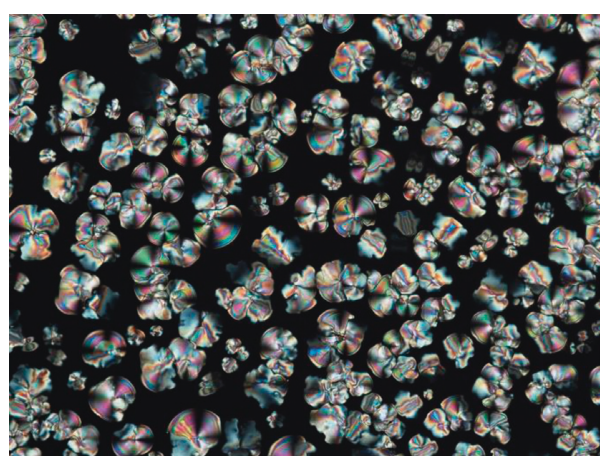

(b)

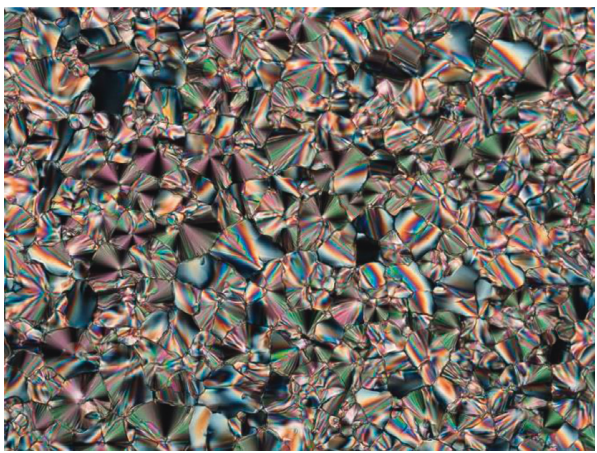

(d)

Figure 4: Pictures taken at the polarizing optical microscope showing the optical textures of $2 \mathrm{a}$ at $170^{\circ} \mathrm{C}(\mathrm{a}), 160^{\circ} \mathrm{C}(\mathrm{b}), 85^{\circ} \mathrm{C}(\mathrm{c})$, and $35^{\circ} \mathrm{C}(\mathrm{d})$.

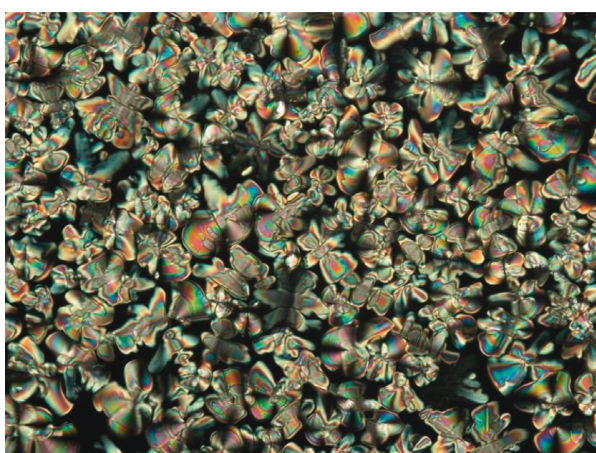

(a)

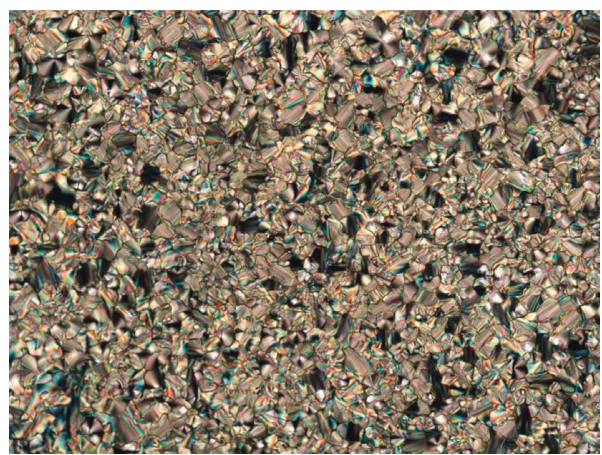

(b)

Figure 5: Pictures taken at the polarizing optical microscope showing the optical textures of $2 \mathbf{b}$ at $175^{\circ} \mathrm{C}$ (a) and $35^{\circ} \mathrm{C}$ (b).

The diffractograms of $\mathbf{2} \mathbf{a}$ and $\mathbf{2} \mathbf{b}$ show a strong maximum from the (100) reflection followed by a series of four weaker sharp peaks with a $d$-spacing ratio of $d / \sqrt{ } 3, d / 2, d / \sqrt{ } 7$, and $d / 4$ from the (110), (200), (210), and (400) reflections for $\mathbf{2 a}$ or $d / \sqrt{ } 3, d / 2, d / \sqrt{ } 7$, and $d / 3$ from the (110), (200), (210), and (300) reflections for $\mathbf{2 b}$, respectively (Figure 6).

It is important to mention that the transition temperatures recorded both during the heating and cooling runs by DSC were slightly shifted towards lower values on subsequent heating-cooling cycles for complexes $\mathbf{2 a}$ and $\mathbf{2 b}$. These observations indicate a possible slight decomposition of the copper(I) complexes on heating above the clearing points. Therefore, a study regarding the thermal stability of these compounds was performed in the next step.
3.3. Thermal Stability of the Ligands and Copper(I) Complexes. The two copper(I) complexes and the BTU ligand were investigated by TG analysis in nitrogen, in the $25-550^{\circ} \mathrm{C}$ temperature range, and the decomposition curves are presented in Figure 7. These TG curves do not contain steps or other indication of mass loss in the $25-160^{\circ} \mathrm{C}$ region, and therefore, the complexes do not contain small molecules (water or ethanol solvent). On the contrary, the results of the thermogravimetric analyses show that the copper(I) complexes 2a and $\mathbf{2 b}$ have a higher thermal stability compared to the BTU ligand 1, and their decomposition started at temperatures around $180^{\circ} \mathrm{C}$. For exemplification, Figure 7 gives the TG curves for the BTU ligand $\mathbf{1}$ and its copper(I) complexes 2a and $\mathbf{2 b}$. The BTU ligand starts decomposing around $160^{\circ} \mathrm{C}$. 
TABLe 2: Temperature dependent X-ray powder diffraction for $\mathrm{Cu}(\mathrm{I})$ compounds.

\begin{tabular}{|c|c|c|c|c|c|c|}
\hline Compound & Mesophase & $T\left({ }^{\circ} \mathrm{C}\right)$ & Indexation & $d$-spacing observed $(\AA)$ & $d$-spacing calculated $(\AA)$ & Lattice parameters $(\AA)^{\mathrm{a}}$ \\
\hline \multirow{6}{*}{$2 a$} & \multirow{6}{*}{$\mathrm{Col}_{\mathrm{h}}$} & \multirow{6}{*}{125} & 100 & 26.91 & 26.91 & \multirow{6}{*}{$a=31.07$} \\
\hline & & & 110 & 15.49 & 15.54 & \\
\hline & & & 200 & 13.42 & 13.46 & \\
\hline & & & 210 & 10.04 & 10.17 & \\
\hline & & & 400 & 6.66 & 6.73 & \\
\hline & & & Broad $^{\mathrm{b}}$ & 4.6 & - & \\
\hline \multirow{6}{*}{$2 b$} & \multirow{6}{*}{$\mathrm{Col}_{\mathrm{h}}$} & \multirow{6}{*}{125} & 100 & 26.51 & 26.51 & \multirow{6}{*}{$a=30.61$} \\
\hline & & & 110 & 15.17 & 15.30 & \\
\hline & & & 200 & 13.18 & 13.26 & \\
\hline & & & 210 & 10.00 & 10.02 & \\
\hline & & & 300 & 8.80 & 8.84 & \\
\hline & & & Broad $^{\mathrm{b}}$ & 4.6 & - & \\
\hline
\end{tabular}

${ }^{\mathrm{a}}$ The $\mathrm{Col}_{\mathrm{h}}$ lattice parameter $\mathrm{a}=2<d_{100}>/ \sqrt{ } 3$. ${ }^{\mathrm{b}}$ Broad peak assigned to molten alkyl chains.

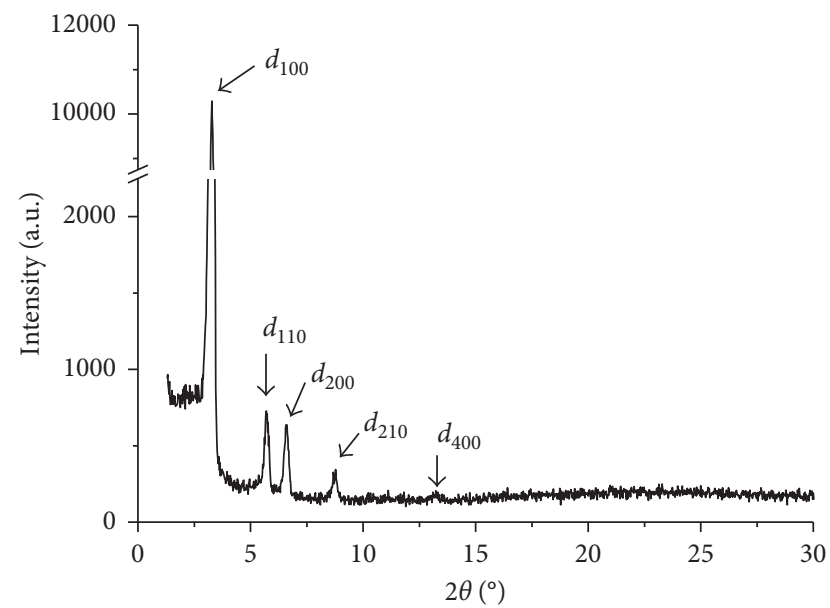

(a)

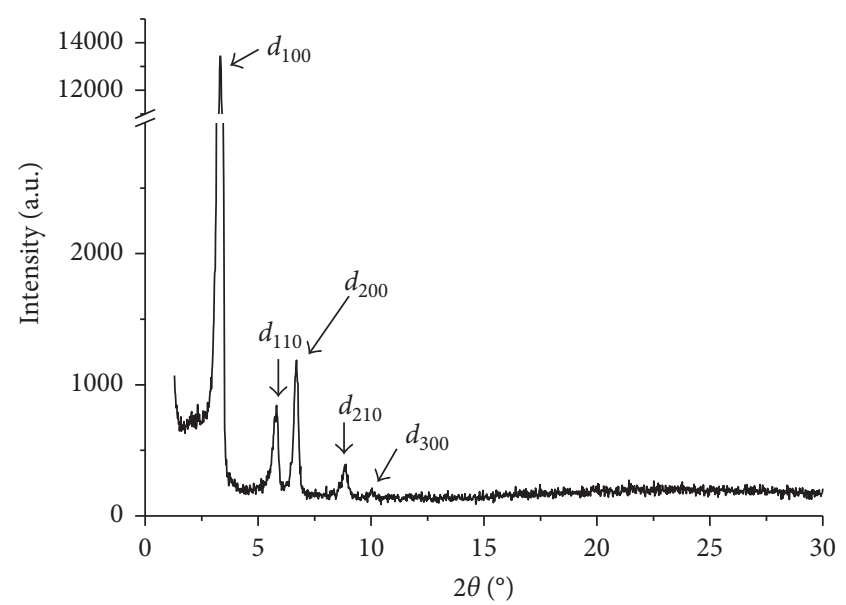

(b)

Figure 6: X-ray powder diffractograms for $\mathrm{Cu}(\mathrm{I})$ compounds: $\mathbf{2 a}$ at $125^{\circ} \mathrm{C}$ (a) and $\mathbf{2 b}$ at $125^{\circ} \mathrm{C}(\mathrm{b})$.

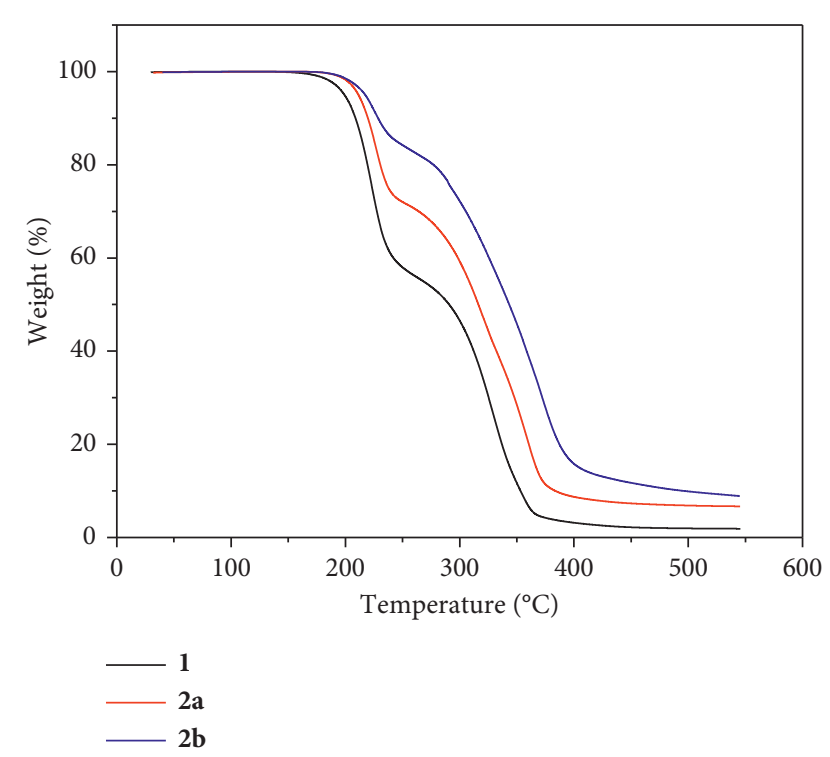

Figure 7: TG curves for ligand $\mathbf{1}$ and its copper(I) complexes $\mathbf{2 a}$ and $\mathbf{2 b}$.
As it can be seen from Figure 7, the two copper(I) complexes undergo complete decomposition up to $500^{\circ} \mathrm{C}$. A small weight loss, less than $2 \%$, was recorded on heating the copper(I) complexes $\mathbf{2} \mathbf{a}$ and $\mathbf{2} \mathbf{b}$ above the clearing points around $180^{\circ} \mathrm{C}$. The slight decomposition observed at temperatures higher than the clearing point could explain the transition temperatures shifting recorded by DSC. Similar observations were found for some palladium(II) complexes with mixed ligands, Schiff bases, and BTU derivatives, reported previously $[59,60]$.

\section{Conclusions}

Three-coordinate copper(I)-containing liquid crystalline materials with columnar mesophases were prepared by using an alkoxy-substituted $N$-benzoylthiourea derivative having a perfluorooctyl group at one end. The new copper(I) complexes exhibit a hexagonal columnar phase over a large temperature range, more than $100^{\circ} \mathrm{C}$, as evidenced by DSC, POM observations, and powder X-ray diffraction analysis. The thermal stability of these copper(I) metallomesogens is 
limited by a slight decomposition on heating above the clearing points $\left(\sim 180^{\circ} \mathrm{C}\right)$.

\section{Data Availability}

The data used to support the findings of this study are included within the article.

\section{Conflicts of Interest}

The authors declare that they have no conflicts of interest.

\section{Acknowledgments}

The authors would like to thank to Dr. Iuliana Pasuk (National Institute of Materials Physics, Magurele, Romania) for her support with XRD measurements.

\section{References}

[1] R. W. Date, E. F. Iglesias, K. E. Rowe, J. M. Elliott, and D. W. Bruce, "Metallomesogens by ligand design," Dalton Transactions, no. 10, pp. 1914-1931, 2003.

[2] J. Torroba and D. W. Bruce, "Metallomesogens," in Comprehensive Inorganic Chemistry II: From Elements to Applications, vol. 8, pp. 837-917, Elsevier Ltd., New York, NY, USA, 2nd edition, 2013.

[3] D. Manaila-Maximean, "New grafted ferrite particles/liquid crystal composite under magnetic field," Journal of Magnetism and Magnetic Materials, vol. 452, pp. 343-348, 2017.

[4] J. M. Gilli, S. Thiberge, and D. Manaila-Maximean, "New aspect of the voltage/confinement ratio phase diagram for a confined homeotropic cholesteric," Molecular Crystals and Liquid Crystals, vol. 417, no. 1, pp. 207-213, 2004.

[5] D. Manaila-Maximean, R. Bena, and A. M. Albu, "Electric and electro-optic investigations on polymer dispersed liquid crystal films," Modern Physics Letters B, vol. 11, pp. 431-440, 1997.

[6] C. Rosu, D. M. Maximean, S. Kundu, P. L. Almeida, and O. Danila, "Perspectives on the electrically induced properties of electrospun cellulose/liquid crystal devices," Journal of Electrostatics, vol. 69, no. 6, pp. 623-630, 2011.

[7] D. Manaila-Maximean and C. Rosu, "Influence of polarizing electric field on electrical and optical properties of PDLC films," Molecular Crystals and Liquid Crystals, vol. 413, no. 1, pp. 9-19, 2004.

[8] E.-K. Fleischmann and R. Zentel, "Liquid-crystalline ordering as a concept in materials science: from semiconductors to stimuli-responsive devices," Angewandte Chemie International Edition, vol. 52, no. 34, pp. 8810-8827, 2013.

[9] S. Laschat, A. Baro, N. Steinke et al., "Discotic liquid crystals: from tailor-made synthesis to plastic electronics," Angewandte Chemie International Edition, vol. 46, no. 26, pp. 4832-4887, 2007.

[10] C. Tschierske, "Development of structural complexity by liquid-crystal self-assembly," Angewandte Chemie International Edition, vol. 52, no. 34, pp. 8828-8878, 2013.

[11] P. Espinet, M. C. Lequerica, and J. M. Martín-Alvarez, "Synthesis, structural characterization and mesogenic behavior of copper(I) n-alkylthiolates," Chemistry-A European Journal, vol. 5, no. 7, pp. 1982-1986, 1999.

[12] M. Benouazzane, S. Coco, P. Espinet, and J. Barbera, "Supramolecular organization in copper(I) isocyanide complexes:
copper(I) liquid crystals from a simple molecular structure," Journal of Materials Chemistry, vol. 11, no. 6, pp. 1740-1744, 2001.

[13] M. Benouazzane, S. Coco, and P. Espinet, "Binuclear mesogenic copper(I) isocyanide complexes with an unusual inorganic core formed by two tetrahedra sharing an edge," Inorganic Chemistry, vol. 41, no. 22, pp. 5754-5759, 2002.

[14] S. Coco, C. Cordovilla, B. Donnio, P. Espinet, M. J. Garcia-Casas, and D. Guillon, "Self-organization of dendritic supermolecules, based on isocyanide-gold(I), -copper(I), -palladium(II), and -platinum(II) complexes, into micellar cubic mesophases," Chemistry-A European Journal, vol. 14, no. 12, pp. 3544-3552, 2008.

[15] R. Dembinski, P. Espinet, S. Lentijo et al., "Fluorophobic effect in metallomesogens-the synthesis and mesomorphism of Ag, $\mathrm{Au}, \mathrm{Cu}, \mathrm{Fe}, \mathrm{Pd}$, and Pt fluorous isocyanide complexes," $\mathrm{Eu}$ ropean Journal of Inorganic Chemistry, vol. 2008, no. 10, pp. 1565-1572, 2008.

[16] R. Chico, E. de Domingo, C. Dominguez et al., "High onedimensional charge mobility in semiconducting columnar mesophases of isocyano-triphenylene metal complexes," Chemistry of Materials, vol. 29, no. 17, pp. 7587-7595, 2017.

[17] R. Ziessel, G. Pickaert, F. Camerel et al., "Tuning organogels and mesophases with phenanthroline ligands and their copper complexes by inter- to intramolecular hydrogen bonds," Journal of the American Chemical Society, vol. 126, no. 39, pp. 12403-12413, 2004.

[18] F. Neve, M. Ghedini, A. M. Levelut, and O. Francescangeli, "Ionic metallomesogens. Lamellar mesophases in copper(I) azamacrocyclic complexes," Chemistry of Materials, vol. 6, no. 1, pp. 70-76, 1994.

[19] L. Douce, A. El-ghayoury, A. Skoulios, and R. Ziessel, "Columnar mesophases from tetrahedral copper(I) cores and Schiff-base derived polycatenar ligands," Chemical Communications, no. 20, pp. 2033-2034, 1999.

[20] A. El-ghayoury, L. Douce, A. Skoulios, and R. Ziessel, "Cation-induced macroscopic ordering of non-mesomorphic modules-a new application for metallohelicates," Angewandte Chemie International Edition, vol. 37, no. 16, pp. 2205-2208, 1998.

[21] H.-D. Lin and C. K. Lai, "Ionic columnar metallomesogens formed by three-coordinated copper(I) complexes," Journal of the Chemical Society, Dalton Transactions, no. 16, pp. 23832387, 2001.

[22] A. Saeed, U. Floerke, and M. F. Erben, "A review on the chemistry, coordination, structure and biological properties of 1-(acyl/aroyl)-3-(substituted) thioureas,," Journal of Sulfur Chemistry, vol. 35, no. 3, pp. 318-355, 2014.

[23] L. Beyer, E. Hoyer, J. Liebscher, and H. Hartmann, "Formation of complexes with n-acyl-thioureas," Zeitschrift für Physikalische Chemie, vol. 21, pp. 81-91, 1981.

[24] P. Muhl, K. Gloe, F. Dietze, E. Hoyer, and L. Beyer, " $N$-acylthioureas-effective extractants for liquid-liquidextraction of metal-ions," Zeitschrift für Physikalische Chemie, vol. 26, pp. 81-94, 1986.

[25] J. Duque, O. Estévez-Hernández, E. Reguera, J. Ellena, and Rodrigo S. Corrêa, "Synthesis, characterization, and single crystal X-ray structure of the 1-furoyl-3-cyclohexylthiourea cadmium chloride complex, $\left.\mathrm{CdC}_{4} \mathrm{H}_{3} \mathrm{OC}(\mathrm{O}) \mathrm{NHC}(\mathrm{S}) \mathrm{NHC}_{6} \mathrm{H}_{11}\right]_{4} \mathrm{Cl}_{2}$," Journal of Coordination Chemistry, vol. 62, no. 17, pp. 2804-2813, 2009.

[26] O. Estévez-Hernández, J. Duque, J. Rodríguez-Hernández, and E. Reguera, "Dinuclear and polymeric $\mathrm{Hg}(\mathrm{II})$ complexes with 1-(2-furoyl)thiourea derivatives: their crystal structure 
and related properties," Polyhedron, vol. 97, pp. 148-156, 2015.

[27] T. Yesilkaynak, "2-Chloro- $N$-((5-chloropyridine-2-yl) carbamothioyl)benzamide and its $\mathrm{Co}(\mathrm{II}), \mathrm{Ni}(\mathrm{II})$ and $\mathrm{Cu}$ (II) metal complexes," Journal of Thermal Analysis and Calorimetry, vol. 124, no. 2, pp. 1029-1037, 2016.

[28] R. S. Correa, K. M. de Oliveira, F. G. Delolo et al., "Ru(II)based complexes with $N$-(acyl)- $N^{\prime}, N^{\prime}$-(disubstituted)thiourea ligands: Synthesis, characterization, BSA- and DNA-binding studies of new cytotoxic agents against lung and prostate tumour cells," Journal of Inorganic Biochemistry, vol. 150, pp. 63-71, 2015.

[29] M. Sternberg, J. Rust, C. W. Lehmann, and F. Mohr, "Synthesis and metal complexes of thiourea ligands containing carbohydrate-derived substituents," Helvetica Chimica Acta, vol. 96, no. 2, pp. 280-288, 2013.

[30] S. S. Hassan, M. M. Shoukry, R. N. Shallan, and R. van Eldik, "Synthesis, characterization, speciation and biological studies on metal chelates of 1-benzoyl(1,2,4-triazol-3-yl)thiourea," Journal of Coordination Chemistry, vol. 70, no. 10, pp. 17611775, 2017.

[31] A. Molter, S. Kathrein, B. Kircher, and F. Mohr, "Anti-tumour active gold(I), palladium(II) and ruthenium(II) complexes with thio- and selenoureato ligands: a comparative study," Dalton Transactions, vol. 47, no. 14, pp. 5055-5064, 2018.

[32] C. Roşu, D. Manaila-Maximean, V. Cîrcu, Y. Molard, and T. Roisnel, "Differential negative resistance in the currentvoltage characteristics of a new palladium (II) metallomesogen," Liquid Crystals, vol. 38, no. 6, pp. 757-765, 2011.

[33] X.-Y. Zhao, C.-B. Zhu, H.-P. Li, Y. Yang, and H. W. Roesky, "Synthesis and characterization of copper(I) halide complexes with $N$-(2,6-diisopropylphenyl)- $N^{\prime}$-benzoylthiourea: monomeric, dimeric, and cage structures," Zeitschrift für anorganische und allgemeine Chemie, vol. 640, no. 8-9, pp. 1614-1621, 2014.

[34] Y. F. Yuan, J. T. Wang, M. C. Gimeno, A. Laguna, and P. G. Jones, "Synthesis and characterisation of copper complexes with $N$-ferrocenoyl- $N^{\prime}$-aryl(alkyl)thioureas," Inorganica Chimica Acta, vol. 324, no. 1-2, pp. 309-317, 2001.

[35] D. Wang, S.-Y. Wu, H.-P. Li, Y. Yang, and H. W. Roesky, "Synthesis and characterization of copper complexes with the $N$-(2, 6-diisopropylphenyl)- $N^{\prime}$-acylthiourea ligands," European Journal of Inorganic Chemistry, vol. 2017, no. 10, pp. 1406-1413, 2017.

[36] A. F. ElHusseiny, A. Eldissouky, A. M. Al-Hamza, and H. H. Hassan, "Structure-property relationship studies of copper(I) complexes of nanosized hypodentate ligands and evaluation of their antitumor and antimicrobial activities," Journal of Coordination Chemistry, vol. 68, no. 2, pp. 241-260, 2015.

[37] G. Li, D.-J. Che, Z.-F. Li, Y. Zhu, and D.-P. Zou, "Versatile coordination patterns in the reaction system of N-benzoyl-N'(2 pyridyl)thiourea with $\mathrm{CuCl}_{2}$. Their reaction conditions, systematic isolation and crystal structures," New Journal of Chemistry, vol. 26, no. 11, pp. 1629-1633, 2002.

[38] D. P. Singh, S. Pratap, S. K. Pandey, R. J. Butcher, and G. Marverti, "N-(naphthyl)- $N$ '-(methoxy carbonyl)thiocarbamide and its $\mathrm{Cu}(\mathrm{I})$ complex: synthesis, spectroscopic, $\mathrm{X}$-ray, DFT and in vitro cytotoxicity study," Journal of Coordination Chemistry, vol. 68, no. 2, pp. 261-276, 2015.

[39] L. Xian, T.-B. Wei, and Y.-M. Zhang, "Synthesis and crystal structure of bis( $N$-o-methylphenyl- $N^{\prime}$-ethoxycarbonylthiourea) copper(I) chloride," Journal of Coordination Chemistry, vol. 57, no. 6, pp. 453-457, 2004.
[40] M. Ilis, M. Bucos, F. Dumitrascu, and V. Cîrcu, "Mesomorphic behaviour of $N$-benzoyl- $N^{\prime}$-aryl thioureas liquid crystalline compounds," Journal of Molecular Structure, vol. 987, no. 1-3, pp. 1-6, 2011.

[41] M. Iliş, M. Micutz, I. Pasuk, T. Staicu, and V. Cîrcu, "Synthesis and liquid crystalline properties of novel fluorinated $\mathrm{N}$ benzoyl thiourea compounds. Effect of perfluoroalkyl chains on the thermal behavior and smectic phases stability," Journal of Fluorine Chemistry, vol. 204, pp. 84-89, 2017.

[42] M. Hird, "Fluorinated liquid crystals-properties and applications," Chemical Society Reviews, vol. 36, no. 12, pp. 2070-2095, 2007.

[43] M. Spengler, R. Y. Dong, C. A. Michal, M. Pfletscher, and M. Giese, "Fluorination of supramolecular liquid crystalstuning tool and analytical probe," Journal of Materials Chemistry C, vol. 5, no. 9, pp. 2235-2239, 2017.

[44] S. Marzouk, A. Khalfallah, B. Heinrich, J. E. Khiari, A. Kriaa, and S. Mérya, "Synthesis and mesomorphic properties of liquid crystals containing a perfluorinated segment via different linkers," Journal of Fluorine Chemistry, vol. 197, pp. 15-23, 2017.

[45] J. Y. Jang and Y. W. Park, "Smectic C mesogens with terminal perfluoroalkyl chains," Molecular Crystals and Liquid Crystals, vol. 606, no. 1, pp. 90-100, 2015.

[46] J. Y. Jang and Y. W. Park, "Synthesis and structural studies of smectic C mesogens with terminal perfluoroalkyl chains," Liquid Crystals, vol. 40, no. 4, pp. 511-515, 2013.

[47] B. Bilgin-Eran, H. Ocak, C. Tschierske, and U. Baumeister, "Synthesis and mesomorphism of fluoroalkylated platinum complexes," Liquid Crystals, vol. 39, no. 4, pp. 467-476, 2012.

[48] A. P. Piccionello, A. Calabrese, I. Pibiri, V. Giacalone, A. Pace, and S. Buscemia, "Synthesis of fluorinated bent-core mesogens (BCMs) containing the 1,2,4-oxadiazole ring," Journal of Heterocyclic Chemistry, vol. 53, no. 6, pp. 1935-1940, 2016.

[49] A. Iwan, "Characterisation and mesomorphic behavior of rod-shaped unsymmetrical imine with a fluorinated chain and a carboxylic group," Molecular Crystals and Liquid Crystals, vol. 528, no. 1, pp. 156-162, 2010.

[50] H. Ocak, B. Bilgin-Eran, C. Tschierske, U. Baumeister, and G. Pelzl, "Effect of fluorocarbon chains on the mesomorphic properties of chiral imines and their complexes with copper(II)," Journal of Materials Chemistry, vol. 19, no. 38, pp. 6995-7001, 2009.

[51] I. B. Douglass and F. B. Dains, "Some derivatives of benzoyl and furoyl isothiocyanates and their use in synthesizing heterocyclic compounds," Journal of the American Chemical Society, vol. 56, no. 3, pp. 719-721, 1934.

[52] J. Imrich, T. Bušová, P. Kristián, and J. Džara, "Synthesis and the 13C NMR spectra of N,N-disubstituted benzoylthioureas and their seleno and oxo analogues," Chemical Papers, vol. 48, pp. 42-46, 1998.

[53] F. Leßmann, L. Beyer, R. Richter, and R. Meusinger, "N-benzoylthiocarbamoyl amino acid ethyl esters as chelate ligands for transition metal ions," Zeitschrift für Naturforschung, vol. 53b, pp. 981-990, 1998.

[54] A. Saeed, Z. Ashraf, M. F. Erben, and J. Simpson, "Vibrational spectra and molecular structure of isomeric 1-(adamantan-1ylcarbonyl)-3-(dichlorophenyl)thioureas," Journal of Molecular Structure, vol. 1129, pp. 283-291, 2017.

[55] L. Qiao, Y. Zhang, W. Hu et al., "Synthesis, structural characterization and quantum chemical calculations on 1(isomeric methylbenzoyl)-3-(4-trifluoromethylphenyl)thioureas," Journal of Molecular Structure, vol. 1141, pp. 309-321, 2017. 
[56] M. E. D. Lestard, D. M. Gil, O. Estévez-Hernández, M. F. Erben, and J. Duque, "Structural, vibrational and electronic characterization of 1-benzyl-3-furoyl-1-phenylthiourea: an experimental and theoretical study," New Journal of Chemistry, vol. 39, no. 9, pp. 7459-7471, 2015.

[57] O. Estévez-Hernández, F. F. Salomón, J. Duque, J. RodríguezHernández, and D. M. Gil, "Synthesis, structural and spectroscopic studies of 1-(2-furoyl)-3-phenylthiourea: a theoretical and experimental approach," Journal of Sulfur Chemistry, vol. 37, no. 5, pp. 555-579, 2016.

[58] D. M. Gil, M. E. Defonsi Lestard, O. Estévez-Hernández, J. Duque, and E. Reguera, "Quantum chemical studies on molecular structure, spectroscopic (IR, Raman, UV-Vis), NBO and Homo-Lumo analysis of 1-benzyl-3-(2-furoyl) thiourea," Spectrochimica Acta Part A: Molecular and Biomolecular Spectroscopy, vol. 145, pp. 553-562, 2015.

[59] M. Ilis, D. Batalu, I. Pasuk, and V. Cîrcu, "Cyclometalated palladium(II) metallomesogens with Schiff bases and $N$ benzoyl thiourea derivatives as co-ligands," Journal of Molecular Liquids, vol. 233, pp. 45-51, 2017.

[60] M. Ilis, M. Micutz, and V. Cîrcu, "Luminescent palladium(II) metallomesogens based on cyclometalated Schiff bases and $N$ benzoyl thiourea derivatives as co-ligands," Journal of Organometallic Chemistry, vol. 836-837, pp. 81-89, 2017. 

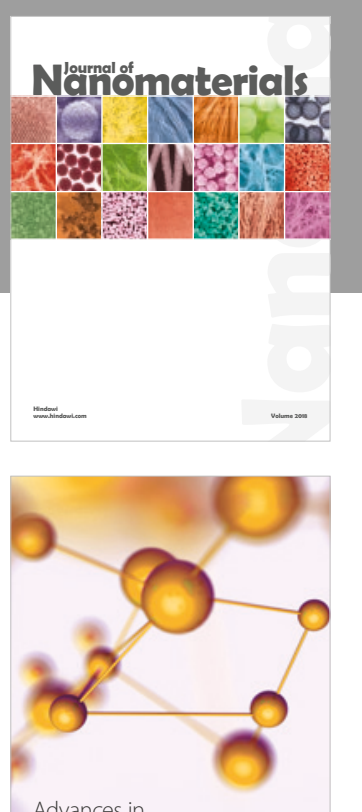

Physical Chemistry
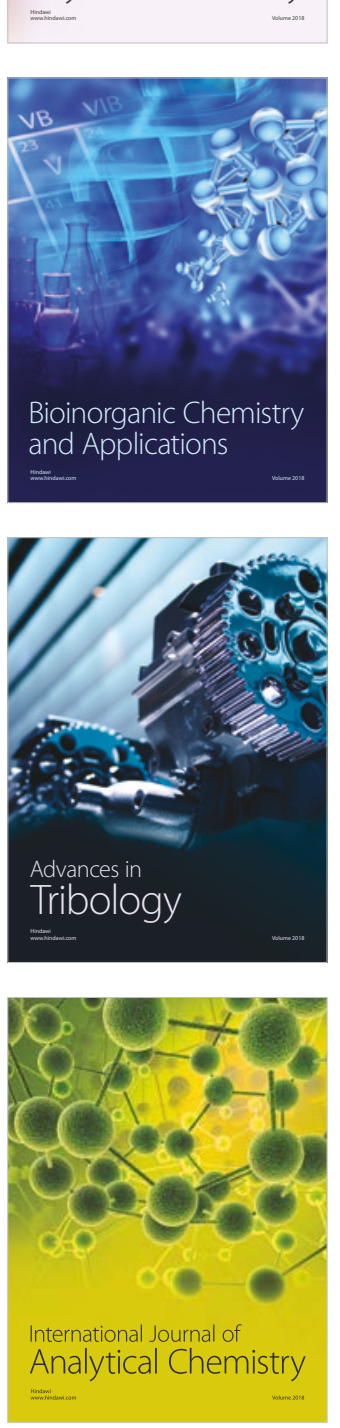

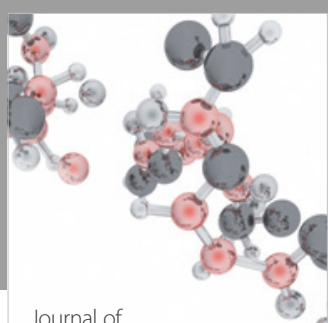

Analytical Methods

in Chemistry

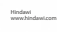

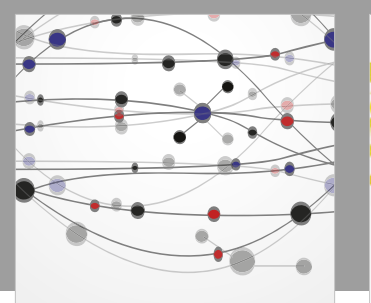

The Scientific World Journal

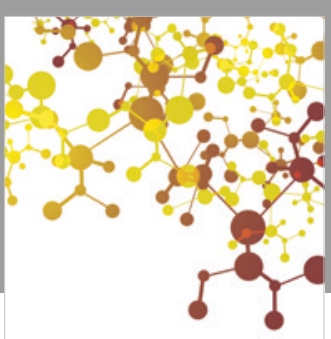

Journal of

Applied Chemistry
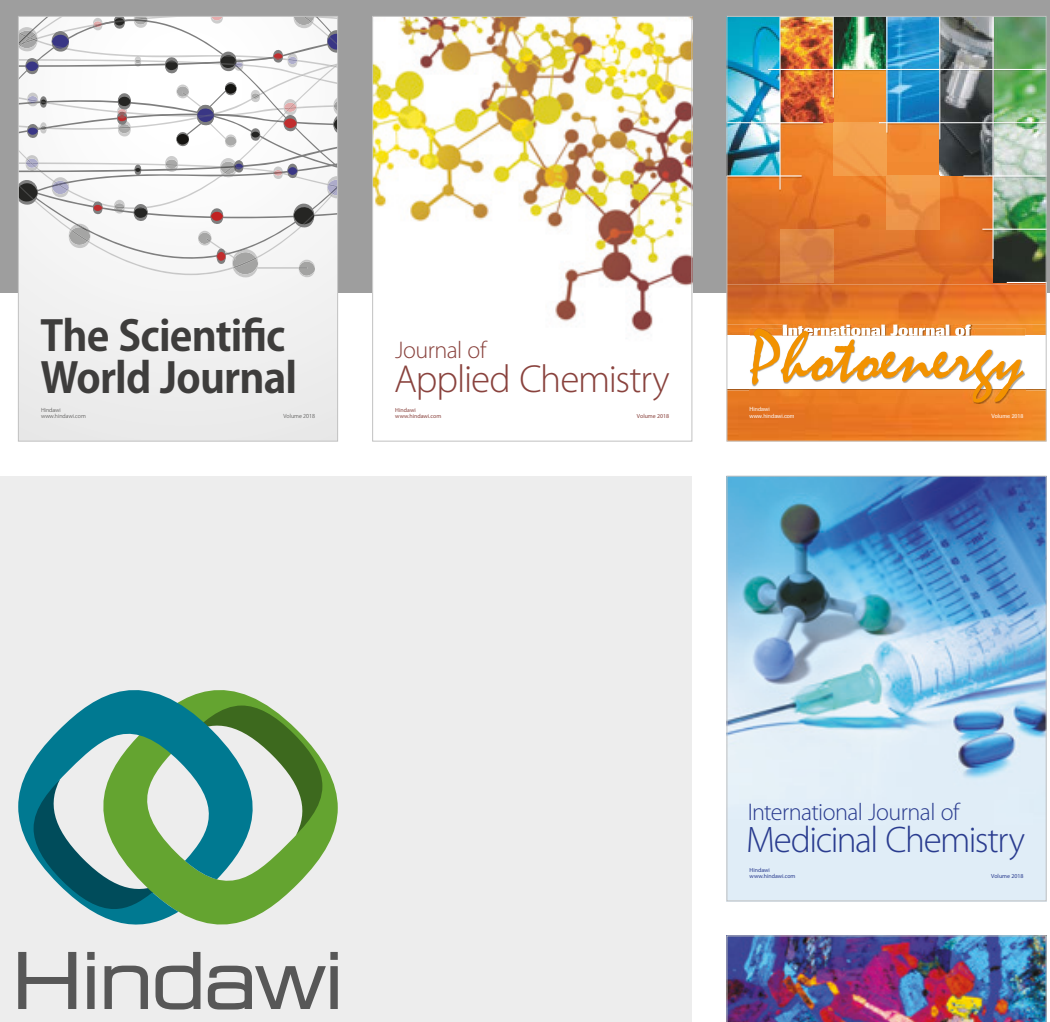

Submit your manuscripts at

www.hindawi.com
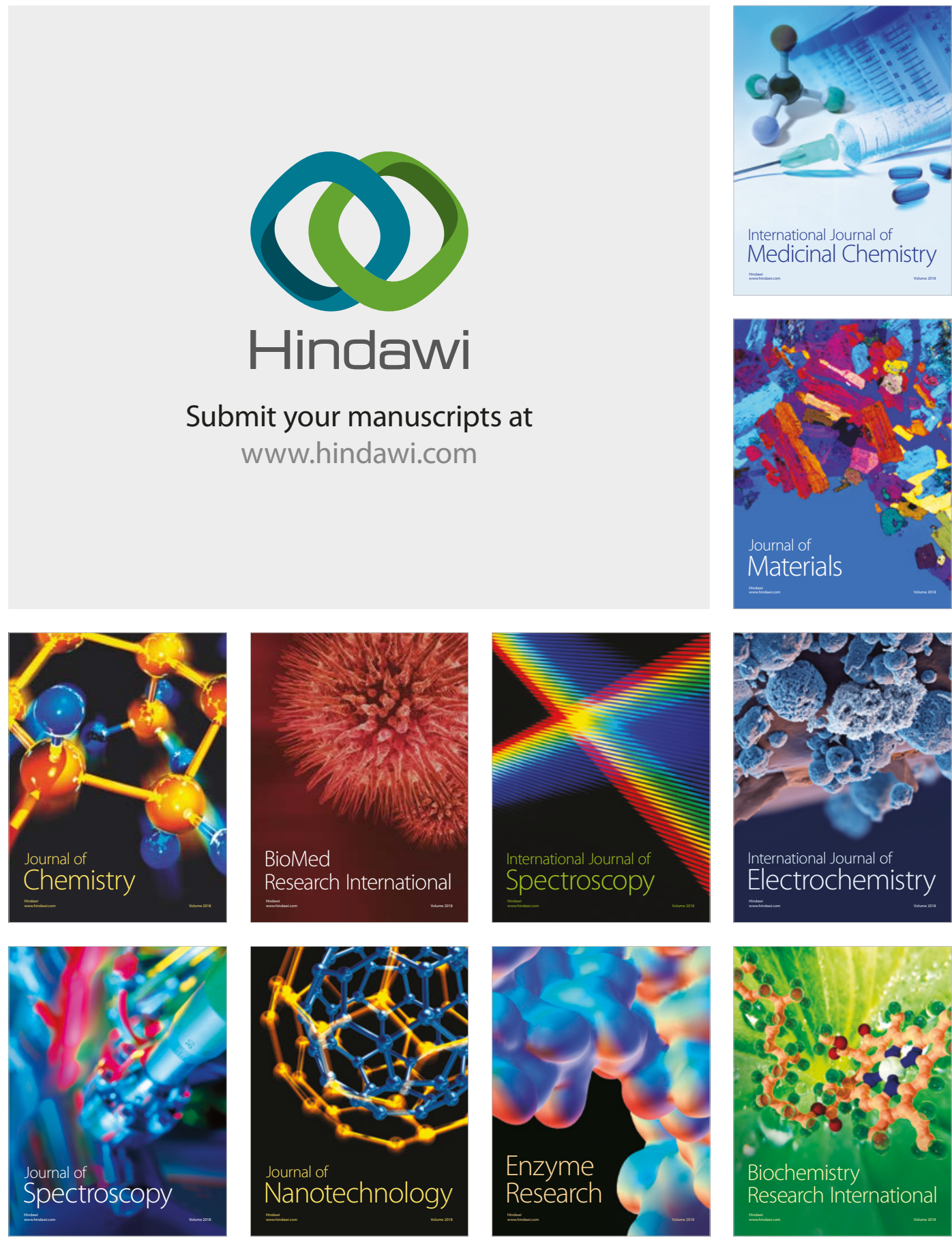
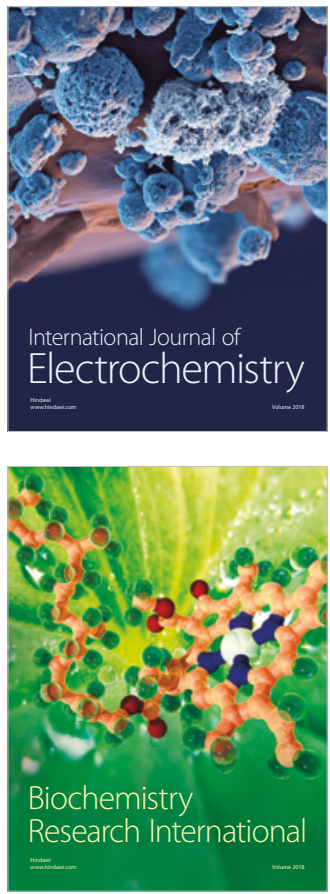